\title{
Analisis Upaya Pemerintah Dalam Menangani Mudik Melalui Peraturan Menteri Perhubungan Nomor 25 Tahun 2020 Pada Masa Covid-19
}

\author{
Ainaya Nadine dan Zulfa Zahara Imtiyaz \\ tiyanaja10@gmail.com \\ Universitas Airlangga
}

\begin{abstract}
Keywords: $\quad$ Abstract
Law Enforcement; Covid-19 is a contagious disease that causes emergencies in the world including Indonesia. Liability; Covid-19; This situation causes all activities to be hampered, especially in terms of mobility that is Transportation. needed to carry out activities. Transportation is an important tool in this regard. The government is demanding that as soon as possible take steps to prevent and control the spread of Covid-19, so a rule or regulation is needed. The spread of Covid-19 in Indonesia, which began in March 2020, continued until the Eid $1441 \mathrm{H}$ took place. It has become a culture and tradition in Indonesia when Eid is to stay in touch with relatives and return to their hometown or usually called mudik. This of course requires a mode of transportation. To prevent the acceleration of the spread of the virus, the government issued a regulation on the prohibition of mudik through Permenhub No. 25/2020. The issuance of this regulation is a government preventive measure in handling Covid-19. However, this causes losses to prospective passengers who have already bought tickets for going home and those who hope to meet with their families. Regarding this, regulation must not only contain regulatory matters such as prohibitions and sanctions for those who violate them but also provide solutions to unwanted things such as compensation as a form of liability. Thus, the author uses the normative juridical research method, as well as statute approach and conceptual approach, where the results of the research are based on legal issues, which are law enforcement by giving different sanctions for each type of transportation stated in Article 6, Article 12, and Article 18 of Permenhub 25/2020. Meanwhile, compensation for prospective passengers who are supposed to go on dates that are prohibited from the government, for the ground, sea, and air transportation, all receive compensation from the carrier.
\end{abstract}

Kata Kunci:
Penegakan
Hukum;
Tanggung
Jawab; Covid-19;
Transportasi.

\begin{abstract}
Abstrak
Covid-19 merupakan penyakit menular yang menyebabkan keadaan darurat di dunia tidak terkecuali Indonesia. Keadaan ini menyebabkan seluruh aktivitas menjadi terhambat khususnya dalam hal mobilitas yang sangat diperlukan untuk menjalankan kegiatan. Angkutan atau transportasi menjadi sarana yang penting dalam hal tersebut. Pemerintah dituntut untuk sesegera mungkin melakukan langkah-langkah pencegahan dan penanggulangan penyebaran Covid-19, sehingga diperlukan sebuah aturan atau regulasi. Penyebaran Covid-19 di Indonesia yang dimulai pada bulan Maret 2020 lalu masih terjadi hingga lebaran $1441 \mathrm{H}$ berlangsung. Sudah menjadi budaya dan tradisi di Indonesia saat lebaran yaitu bersilaturahmi ke kerabat dan pulang ke kampung halaman atau biasa disebut mudik. Hal tersebut tentunya membutuhkan moda transportasi. Untuk mencegah percepatan penyebaran virus, pemerintah menerbitkan aturan larangan mudik melalui Permenhub No. 25/2020. Penerbitan aturan tersebut sebagai langkah preventif pemerintah dalam penanganan Covid-19. Namun, hal ini menyebabkan kerugian terhadap calon penumpang yang terlanjur membeli tiket untuk mudik
\end{abstract}


Ainaya Nadine: Analisis Upaya Pemerintah...

serta orang-orang yang berharap dapat bertemu dengan keluarganya. Terhadap hal tersebut, sebuah regulasi tentunya selain berisi hal-hal yang mengatur seperti larangan-larangan serta sanksi bagi yang melanggarnya, tentu juga memberikan solusi atas hal-hal yang tidak diinginkan seperti ganti rugi sebagai bentuk tanggung jawab. Sehingga, penulis menggunakan metode penelitian yuridis normatif, serta menggunakan pendekatan perundang-undangan dan pendekatan konseptual, dimana hasil penelitian berdasarkan isu hukum yakni penegakan hukum dengan pemberian sanksi yang berbeda pada tiap jenis transportasi yang tertera pada Pasal 6, Pasal 12, dan Pasal 18 Permenhub 25/2020. Sedangkan terhadap ganti rugi calon penumpang, pada tanggal-tanggal yang dilarang mudik, baik pengguna transportasi darat, laut, maupun udara semuanya mendapatkan ganti rugi dari pengangkut.

\section{Pendahuluan}

Copyright $\odot 2020$ Universitas Airlangga

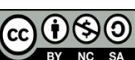

Pengangkutan atau biasa disebut dengan transportasi merupakan salah satu aspek penting dalam kehidupan. Menurut Purwosutjipto pengangkutan adalah perjanjian timbal balik antara pengangkut dengan pengirim, dimana pengangkut mengikatkan diri untuk menyelenggarakan pengangkutan barang dan/ atau orang dari suatu tempat ke tempat tujuan tertentu dengan selamat, sedangkan pengirim mengikatkan diri untuk membayar uang angkutan. ${ }^{1}$ Secara garis besar, moda pengangkutan dapat diklasifikasikan sebagai berikut:

a. Pengangkutan darat melalui jalan raya dan kereta api;

b. Pengangkutan laut; dan

c. Pengangkutan udara.

Angkutan sebagai salah satu sarana yang mempunyai peranan penting dalam kehidupan khususnya dalam menjalankan roda perekonomian untuk memenuhi kebutuhan hidup, dimana manusia membutuhkan angkutan sebagai sarana yang tak terpisahkan dari mata rantai perekonomian. Namun, beberapa bulan terakhir dunia sedang menghadapi krisis pandemi Coronavirus Disease 2019 atau biasa disebut dengan Covid-19.

Pandemi Covid-19 telah menyebar dengan cepat ke seluruh dunia yang menyebabkan berhentinya rutinitas harian dan dalam beberapa kasus ekstrim, Covid-19 telah merenggut jutaan nyawa. Seluruh dunia berada dalam mode 1991).[2].

1 Purwosutjipto, Pengertian Pokok Hukum Dagang Indonesia 3: Hukum Pengangkutan (Djambatan 
krisis, tidak terkecuali Indonesia. Covid-19 pertama dilaporkan di Indonesia pada tanggal 2 Maret 2020 sejumlah dua kasus. ${ }^{2}$ Data 8 Juni 2020 menunjukkan kasus yang terkonfirmasi berjumlah 32.033 kasus dan 1.883 kasus kematian. ${ }^{3}$ Sehingga, pada bulan Idul Fitri 1441 Hijriah berlangsung di Indonesia pada akhir bulan Mei kemarin, setidaknya kasus Covid-19 mencapai kisaran 20.000 kasus. Dalam hal ini, pemerintah Indonesia telah menetapkan wabah Covid-19 sebagai bencana nasional. Dampak Covid-19 telah memengaruhi banyak sektor dalam kegiatan seharihari, salah satunya dalam sektor transportasi. Dampak yang sangat besar dalam sektor transportasi menyebabkan terjadinya penurunan aktivitas di transportasi darat, laut, dan bandar udara. Pemerintah juga membatasi mobilisasi, baik orang maupun barang antar daerah di dalam negeri. Akibatnya, banyak proses produksi berhenti atau menurun yang berimbas terhadap aktivitas ekonomi secara lokal, domestik, regional, dan global.

Dalam rangka mencegah Covid-19 semakin menyebar, pemerintah menerapkan beberapa kebijakan untuk termasuk menjaga jarak fisik, seperti Pembatasan Sosial Berskala Besar (PSBB) dan larangan mudik lebaran 2020. Untuk kebijakan transportasi di masa pandemi Covid-19, Indonesia telah mengeluarkan dua Permenhub yaitu Peraturan Menteri Perhubungan Nomor 18 Tahun 2020 tentang Pengendalian Transportasi Dalam Rangka Pencegahan Penyebaran Virus COVID 19 tanggal 09 April 2020 dan Peraturan Menteri Perhubungan Nomor 25 Tahun 2020 tentang Pengendalian Transportasi Selama Masa Mudik Idul Fitri 1441 H yang berlaku sejak 24 April 2020. Dalam jurnal ini, penulis hanya akan fokus membahas Peraturan Menteri Perhubungan Nomor 25 Tahun 2020 yang berkaitan dengan mudik.

Beberapa kebijakan yang dikeluarkan oleh pemerintah terkait transportasi di Indonesia sering berubah-ubah. Semua perubahan berlangsung dalam waktu

${ }^{2}$ World Health Organization, 'Situation Report (World Health Organization)' (World Health Organization, 2020) <https://www.who.int/docs/default-source/coronaviruse/situation-reports/20200302-sitrep-42-covid-19.pdf?sfvrsn=224c1add_2> accessed 8 June 2020.

${ }^{3}$ Kementerian Kesehatan Republik Indonesia, 'Info Infeksi Emerging Corona Virus (Infeksi Emerging 2020)' (Kementerian Kesehatan Republik Indonesia, 2020) <https://covid19.kemkes.go.id/ category/situasi-infeksi-emerging/info-corona-virus/\#.XwsRcSgzbIU> accessed 8 June 2020. 
Ainaya Nadine: Analisis Upaya Pemerintah...

singkat di tengah pandemi Covid-19 ini membuat masyarakat bingung untuk menentukan sikap. Tidak heran banyak ditemukan kasus di lapangan bahwa dengan adanya kebijakan berupa Peraturan Menteri Perhubungan dalam rangka memotong penyebaran Covid-19 tidak mengurungkan niat masyarakat untuk tetap bepergian dari satu tempat ke tempat yang lainnya, terlebih saat mendekati Idul Fitri $1441 \mathrm{H}$. Penggunaan transportasi pribadi menjadi satu-satunya pilihan yang dimiliki oleh para pemudik yang nekat untuk mudik pada saat Covid-19.

Presiden Joko Widodo resmi melarang mudik bagi seluruh masyarakat Indonesia. Hal tersebut bertujuan untuk mencegah mobilitas penduduk dari suatu wilayah ke wilayah lainnya yang dapat meningkatkan risiko penyebaran Covid-19. ${ }^{4}$ Larangan tersebut berlaku di seluruh Indonesia, terlebih lagi bagi wilayah Jakarta, Bogor, Depok, Tangerang, Banten (Jabodetabek), daerah yang menerapkan Pembatasan Sosial Berskala Besar (PSBB) dan wilayah zona merah Covid-19. Seperti yang diketahui bahwa Covid-19 dapat menyebar melalui droplet, dan penularan terjadi melalui kontak jarak dekat. Dikarenakan penularannya yang mudah ini, masyarakat dianjurkan untuk menjaga jarak fisik atau physical distancing saat berada di tempat umum. Hal inilah yang menjadi salah satu dasar pertimbangan pemerintah melarang mudik. Permasalahan bukan hanya sekedar berdekatan dengan sesama pemudik yang berbahaya, namun tidak ada yang pernah tau apakah pembawa virus Covid-19 atau carrier ini bisa dari petugas tiket, penumpang lain, atau mungkin pemudik itu sendiri. Suasana lebaran yang kental dengan silaturahmi secara fisik kini harus tertunda dalam rangka mengurangi pergerakan atau perpindahan yang melibatkan manusia dari satu tempat ke tempat lain demi terputusnya rantai penyebaran Covid-19.

Keberhasilan pemerintah dalam hal melarang masyarakatnya untuk mudik dapat ditinjau dari produk hukum berupa Peraturan Menteri Perhubungan No. 25 tahun 2020. Peraturan tersebut diharapkan mampu untuk menciptakan

4 Muhammad Choirul Anwar, 'PHK Sudah Terjadi, Sektor Transportasi Terpuruk Kena Corona' (CNBC Indonesia, 2020) <https://www.cnbcindonesia.com/news/20200427110116-4-154631/ phk-sudah-terjadi-sektor-transportasi-terpuruk-kena-corona> accessed 8 June 2020. 
keadaan yang dikehendaki oleh hukum, hal ini berkaitan dengan kemampuan pemerintah dalam membatasi penyebaran Covid-19 dengan pemberian sanksi kepada masyarakat yang melanggar sebagai sebuah bentuk penegakan hukum. Selain itu, penulis juga akan membahas mengenai kemampuan pemerintah untuk memberikan perlindungan bagi masyarakat yang menggunakan angkutan umum dalam rencana mudiknya dengan pemberian aturan ganti rugi.

Upaya pemerintah dalam menegakkan hukum dan melindungi masyarakat berkaitan erat dengan persoalan penerapan dan pelaksanaan hukum dalam itu sendiri demi tercapainya tujuan hukum. Berdasarkan hal tersebut, diperlukan pengaturan dan praktek yang ideal yang harus dilakukan mengenai pengangkutan dalam masa pandemi Covid-19 ini. Segala aspek yang berkaitan dengan pelaksanaan angkutan terutama terhadap penegakan hukum dan tanggung jawab pengusaha angkutan menjadi fokus penulis.

\section{Isu Hukum}

Tidak semua lapisan masyarakat mematuhi peraturan yang dikeluarkan oleh pemerintah untuk menanggulangi pandemi Covid-19. Sosialisasi dan pengawasan dilakukan pemerintah dengan bekerja sama dengan berbagai kalangan organisasi masyarakat ataupun perangkat pemerintahan. Banyak yang masih mempertahan ego dan tetap nekat untuk melakukan perjalanan mudik dan tidak sedikit yang dapat lolos dari pemantauan. Selain itu adanya pengecualian yang terdapat di Peraturan Menteri Perhubungan No. 25 tahun 2020 menimbulkan kelonggaran bagi beberapa pihak untuk dapat melakukan perjalanan yang dinilai dapat meningkatkan mobilitas dan membuat upaya pencegahan penyebaran Covid-19 dirasa sia-sia. Selain itu, beberapa perjalanan transportasi umum yang ditiadakan karena adanya Permenhub No. 25 tahun 2020 menyebabkan banyak calon penumpang yang telah membeli tiket untuk mudik menggunakan transportasi umum menjadi batal karena pembatasan yang dilakukan pemerintah.

Berdasarkan latar belakang di atas, adapun yang menjadi isu hukum dalam artikel ini adalah: 
Ainaya Nadine: Analisis Upaya Pemerintah...

1. Penegakan hukum terhadap pelanggaran Permenhub No. 25/2020.

2. Perlindungan hukum terhadap calon penumpang berdasarkan Permenhub No. 25/2020.

\section{Metode}

Dalam penulisan ini, penulis menggunakan metode penelitian yuridis normatif, yakni tipe penelitian hukum yang menitikberatkan pada suatu norma yang merupakan asas atau prinsip tingkah laku. ${ }^{5}$ Dalam penulisan ini, penulis melakukan penelitian yang dilakukan terhadap peraturan perundang-undangan yaitu Peraturan Menteri Perhubungan Nomor 25 Tahun 2020 tentang Pengendalian Transportasi Selama Masa Mudik Idul Fitri Tahun 1441 Hijriah Dalam Rangka Pencegahan Penyebaran Corona Virus Disease 2019 (COVID-19). Metode penelitian hukum normatif adalah suatu prosedur penelitian ilmiah untuk menemukan kebenaran berdasar logika keilmuan hukum dari sisi normatifnya. ${ }^{6}$ Penelitian hukum normatif berawal dari ketidakjelasan norma, baik karena kekosongan norma, kekaburan norma, maupun pertentangan norma (konflik norma). Norma hukum dapat berupa hukum positif bentukan lembaga Perundang-undangan (Undang-Undang Dasar, kodifikasi, Undang-Undang, Peraturan Pemerintah, dan seterusnya) dannorma hukum tertulis bentukanlembaga peradilan (judgemadelaw), serta norma hukum tertulis buatan pihak-pihak yang berkepentingan (kontrak, rancangan Undang-Undang). ${ }^{7}$ Untuk memperdalam, penulis juga menggunakan pendekatan perundang-undangan (statute approach) dan pendekatan konsep (conceptual approach). Penelitian normatif tentunya menggunakan pendekatan perundang-undangan, karena yang dikaji adalah aturan hukum yang menjadi tema dalam penulisan ini. Mengenai pendekatan konsep yang merupakan pendekatan yang beranjak dari pandangan-pandangan dan doktrin-doktrin yang berkembang di dalam ilmu hukum. ${ }^{8}$ Dalam penulisan ini, pendekatan konseptual dilihat dari

5 Peter Mahmud Marzuki, Penelitian Hukum: Edisi Revisi (Kencana 2005).[54].

6 Johny Ibrahim, Teori Dan Metodologi Penelitian Hukum Normatif (Bayu Media 2007).[57].

Abdulkadir Muhammad, Hukum Dan Penelitian Hukum (Citra Aditya Bakti 2004).[52].

8 Marzuki (n 5)., Op.Cit.[177]. 
aspek tanggung jawab yang diatur di dalam Permenhub ini. Upaya pemerintah dalam melindungi masyarakatnya dapat ditemukan secara implisit dalam konsep hukum yang ada di Permenhub. Penulis dalam meneliti, memahami konsep mengenai tanggung jawab dari melalui pandangan-pandangan dan doktrindoktrin yang ada.

\section{Penegakan Hukum dan Pengawasan kepada Pelanggar}

Dalam kehidupan, tentunya diperlukan suatu peraturan perundangundangan sebagai alat negara dan pedoman manusia dalam menjalaninya. Peraturan perundang-undangan sebagai alat negara digunakan untuk mengatur warga negaranya yang boleh atau tidak boleh dilakukan. Secara umum tujuan pembentukan perundang-undangan adalah mengatur dan menata kehidupan dalam suatu negara supaya masyarakat yang diatur oleh hukum itu memperoleh kepastian, kemanfaatan dan keadilan di dalam kehidupan bernegara dan bermasyarakat. ${ }^{9}$ Peraturan perundang-undangan sebagai hukum yang tertulis yang diberi bentuk sejak awal diharapkan bahwa dalam pelaksanaannya akan memberikan kepastian hukum. Disadari bahwa suatu hukum tertulis mengandung banyak kelemahan, tetapi juga memiliki kelebihan dibanding dengan hukum yang tidak tertulis. Peranan peraturan perundang-undangan semakin penting sebagai tuntutan asas legalitas sebagai salah satu ciri negara hukum. Dalam Negara kesejahteraan modern, tatkala menyusun suatu rencana, peraturan perundang-undangan semakin penting baik sebagai kerangka rencana itu sendiri, maupun sebagai instrumen pemandu dalam melaksanakan suatu rencana. ${ }^{10}$ Sehingga, menjadi penting adanya suatu peraturan perundang-undangan dalam negara hukum.

Mengenai hierarki peraturan perundang-undangan, hal ini diatur dalam Pasal 7 ayat (1) Undang-Undang Nomor 12 Tahun 2011 tentang Pembentukan

\footnotetext{
9 Maria Farida Indrati S, Ilmu Perundang-Undangan: Proses Dan Teknik Pembentukannya (Kanisius 2007).

${ }^{10}$ Jalaluddin, 'Hakikat Dan Fungsi Peraturan Perundang-Undangan Sebagai Batu Uji Kritis Terhadap Gagasan Pembentukan Perda Yang Baik' (2011) 6 Aktualita <http://jurnal.untad.ac.id/ jurnal/index.php/AKTUALITA/article/view/2481>.[7].
} 
Ainaya Nadine: Analisis Upaya Pemerintah...

Peraturan Perundang-Undangan. Disamping jenis peraturan perundangundangan yang disebutkan dalam Pasal 7 ayat (1) UU No. 12/2011 juga dikenal jenis peraturan perundang-undangan lainnya, baik yang dikeluarkan oleh badan/ lembaga/pejabat pemerintah pusat seperti; Keputusan Presiden (Keppres), Peraturan Menteri (Permen), dan Keputusan Menteri (Kepmen), maupun peraturan perundang-undangan yang dikeluarkan oleh pemerintah daerah, seperti: Peraturan Gubernur, Peraturan Bupati, Peraturan Walikota, Keputusan Gubernur, Keputusan Bupati, dan Keputusan Walikota. ${ }^{11}$ Namun, fokus dalam penulisan ini yaitu Peraturan Menteri No. 25/2020, dimana Peraturan Menteri tidak disebutkan secara eksplisit dalam hierarki peraturan perundang-undangan yang tercantum di dalam Pasal 7 ayat (1) UU No. 12/2011. Apabila dilakukan penafsiran secara sistematis, kedudukan Peraturan Menteri dapat dilihat dalam Pasal 8 ayat (2) UU No. 12/2011. Pasal 8 ayat (2) UU No. 12/2011 menyatakan bahwa "Peraturan Perundangundangan sebagaimana dimaksud pada ayat (1) diakui keberadaannya dan mempunyai kekuatan hukum mengikat sepanjang diperintahkan oleh Peraturan Perundang-undangan yang lebih tinggi atau dibentuk berdasarkan kewenangan". Dalam pasal tersebut memiliki makna bahwa kedudukan Peraturan Menteri yang dibentuk setelah berlakunya UU No.12/2011, baik yang dibentuk atas dasar perintah peraturan perundang-undangan yang lebih tinggi maupun yang dibentuk atas dasar kewenangan di bidang urusan pemerintahan tertentu yang ada pada menteri, berkualifikasi sebagai peraturan perundang-undangan. ${ }^{12}$ Sehingga Permenhub tetap memiliki kekuatan hukum mengikat.

Adanya pandemi Covid-19 yang terus meluas di berbagai belahan dunia termasuk Indonesia membawa perubahan signifikan terhadap kehidupan. Dengan keadaan seperti ini, maka diperlukan adanya penanggulangan

11 Zairin Harahap, 'Pengaturan Tentang Ketentuan Sanksi Dalam Peraturan Daerah', (2006), Vol 13, Jurnal Hukum.[' (2006) 13 Jurnal Hukum Ius Quia Iustum <https://journal.uii.ac.id/IUSTUM/article/view/4723>.[38].

12 Bilal Dewansyah, 'Kedudukan Peraturan Menteri Dalam Hierarki Peraturan Perundang-Undangan' (Hukum Online, 2014) <https://www.hukumonline.com/klinik/detail/ulasan/ lt5264d6b08c174/kedudukan-peraturan-menteri-dalam-hierarki-peraturan-perundang-undangan/> accessed 8 June 2020. 
dalam berbagai aspek, salah satunya dalam hal peraturan. Pemerintah pusat dituntut untuk sesegera mungkin menangani pandemi Covid-19 ini, sehingga diterbitkanlah pengaturan-pengaturan mengenai protokol kesehatan di berbagai macam sektor termasuk sektor transportasi dalam rangka pengawasan sebagai langkah preventif. Transportasi merupakan hal penting sebagai sarana untuk melakukan kegiatan aktivitas sehari-hari untuk berpindah dari suatu tempat ke tempat tujuan dengan selamat. Merebaknya pandemi Covid-19 pada saat Lebaran 2020 kemarin tentu menjadi penghalang bagi orang-orang yang merayakannya untuk bersilaturahmi ke berbagai tempat bahkan untuk pulang ke kampung halaman yang membutuhkan sarana transportasi. Hal ini sudah barang tentu menjadi kewenangan pemerintah dalam membentuk peraturan dalam rangka peran pemerintah melakukan pengawasan untuk menanggulangi penyebaran Covid-19 di sektor transportasi khususnya oleh Kementerian Perhubungan, maka, dibentuklah Peraturan Menteri Perhubungan (Permenhub) No. 25/2020. Permenhub ini merupakan salah satu upaya pemerintah dalam membatasi mudik agar mencegah penyebaran covid-19.

Setiap peraturan tentu memuat suatu bentuk aturan yang bersifat preventif dan bersifat represif. Pengawasan merupakan langkah preventif untuk memaksakan kepatuhan, sedangkan penerapan sanksi merupakan langkah represif untuk memaksakan kepatuhan. ${ }^{13}$ Pengawasan yang merupakan langkah preventif tersebut berupa dibuatnya peraturan perundang-undangan dalam rangka mencegah penyebaran virus sesuai dengan protokol kesehatan salah satunya Permenhub No. 25/2020. Sedangkan, sanksi merupakan langkah represif sebagai bentuk upaya penegakan hukum dan merupakan bagian penutup yang penting di dalam hukum. Dalam Permenhub No. 25/2020 diatur mengenai sanksi bagi pelanggar yang menggunakan transportasi pada saat mudik lebaran 1441 H. Namun, dalam penerapan sanksi itu sendiri perlu dipertanyakan apakah upaya penegakan hukum tersebut sudah cukup bagi pelanggar ataukah malah

\footnotetext{
13 Philipus M. Hadjon, 'Penegakan Hukum Administrasi Dalam Pengelolaan Lingkungan Hidup' (1995) 2 Jurnal Hukum Ius Quia Iustum.[46].
} 
Ainaya Nadine: Analisis Upaya Pemerintah...

merugikan. Namun, masih banyak masyarakat yang tidak mengindahkan Permenhub tersebut. Tercatat sebanyak 35.945 kendaraan yang dipaksa putar balik selama pelaksanaan 15 hari Operasi Ketupat 2020 yang dilaksanakan sejak 24 April hingga 8 Mei $2020 .{ }^{14}$ Sehingga, diperlukan adanya tindakan represif atas pelanggaran berupa sanksi. Sanksi yang diterapkan dalam Permenhub No. 25/2020 merupakan jenis sanksi administratif dimana bentuk sanksi administratif dapat berupa Uang Paksa (dwangsom); Denda administrasi; Pencabutan KTUN yang menguntungkan (misalnya izin); Uang jaminan; Bentuk-bentuk lain/ khusus misalnya peringatan, atau mengumumkan nama pencemar. ${ }^{15}$

Permenhub No. 25/2020 memberlakukan sanksi yang dituangkan dalam Pasal 6 untuk angkutan darat; Pasal 12 untuk angkutan darat kereta api; Pasal 18 untuk angkutan laut; Pasal 25 untuk angkutan udara. Semua jenis sanksi yang diberlakukan tersebut merupakan jenis sanksi administratif sesuai dengan ketentuan peraturan perundang-undangan dimana dalam hal ini merujuk pada Undang-Undang Nomor 6 Tahun 2018 tentang Kekarantinaan Kesehatan berupa denda hingga Rp 100 juta bagi mereka yang melanggar larangan mudik. Sedikit berbeda dari yang lain, untuk transportasi laut, dalam Pasal 18 menyebutkan sanksi berupa peringatan tertulis, tidak diberikan pelayanan di pelabuhan hingga pencabutan izin SIUPAL.

Dalam prakteknya, pengenaan sanksi tersebut kurang berjalan dengan baik, contohnya pada transportasi darat jalan raya. Masih banyak yang melanggar dengan nekat mudik ke luar kota bahkan dari dan/ atau ke tempat yang dinyatakan zona merah Covid-19. Namun, pengawasan tersebut kurang berjalan dengan baik karena para pelanggar tidak dikenakan sanksi sesuai dengan Permenhub 25/2020. Misalnya, pelanggar hanya melakukan putar balik ke tempat asal. Hal ini dibuktikan dalam salah satu daerah yakni di Bekasi, Jawa Barat bahwa Kepala Korps Lalu Lintas Polri Irjen Pol Istiono mengatakan sanksi

\footnotetext{
14 Rahmanto Elfian, 'Meski Dilarang, Masih Banyak Yang Paksa Mudik' (Portal Surabaya, 2020) <https:// portalsurabaya.pikiran-rakyat.com/nasional/pr-22380273/meski-dilarang-masih-banyak-yang-paksa-mudik> accessed 9 June 2020.

15 Philipus M. Hadjon (n 13)., Op.Cit,[47].
} 
maksimal bagi warga yang nekat mudik selama pelaksanaan Operasi Ketupat 2020 adalah diputarbalikkan ke rumah masing-masing. ${ }^{16}$ Dengan demikian tidak ada sanksi berupa denda. Hal ini dirasa tidak sejalan dengan apa yang diarahkan oleh pemerintah melalui peraturan Permenhub tersebut.

Terdapat kritik bahwa lebih baik mengenakan sanksi berupa tilang, tipiring (tindak pidana ringan), atau Acara Pidana Singkat (APS). Tindak pidana ringan sendiri merupakan tindak pidana yang diatur dalam Pasal 364, 373, 379, 384, 407 dan 482 KUHP yang diancam dengan pidana penjara paling lama 3 (tiga) bulan. Merujuk pada ketentuan-ketentuan tersebut, tindak pidana ringan adalah tindak pidana yang ancaman hukumannya adalah penjara atau kurungan paling lama tiga bulan, atau denda sebanyak-banyaknya Rp7.500 (dengan penyesuaian). ${ }^{17}$ Bahwa, hal ini kurang tepat, karena berdasarkan hierarki Permenhub tidak dapat memuat ketentuan pidana selain UU dan Peraturan Daerah (Perda). Hal ini disebutkan dalam Pasal 15 ayat (1) UU No. 12/2011 bahwa materi muatan mengenai ketentuan pidana hanya dapat dimuat dalam Undang-Undang; Perda Provinsi; Perda Kabupaten/Kota. Selain itu, menurut ahli hukum pidana Abdul Ficar Hadjar menegaskan bahwa hal tersebut tidak bisa dipenuhi karena tidak dapat dikategorikan sebagai "tindakan kriminal", berbeda dengan para pelanggar peraturan lalu lintas. ${ }^{18}$

Dengan adanya hal seperti itu, dapat diartikan bahwa pemerintah telah berupaya memberikan sanksi bagi pelanggar yang nekat mudik dalam langkah pengawasan penyebaran covid-19. Namun, dalam realitanya, hal tersebut kurang diimbangi dengan pengawasan yang ketat, sehingga para pemudik masih nekat melakukan mudik.

${ }^{16}$ Ferry Hidayat (Redaksi Warta Ekonomi Online), 'Tak Ada Denda Rp 100 Juta Untuk Yang Nekat Mudik, Tapi...' (Warta Ekonomi, 2020) <https://Www.Wartaekonomi.Co.Id/Read283321/ Tak-Ada-Denda-Rp100-Juta-Untuk-Yang-Nekat-Mudik-Tapi>, Dikunjungi Pada 9 Juni 2020.' (Warta Ekonomi Online, 2020) <https://www.wartaekonomi.co.id/read283321/tak-ada-denda-rp100-jutauntuk-yang-nekat-mudik-tapi> accessed 9 June 2020.

17 Adi Briantika, 'Hasrat Represif Negara Dibalik Penerapan PSBB Yang Kurang Maksimal' (Tirto.id, 2020) < https:/ / tirto.id/hasrat-represif-negara-di-balik-penerapan-psbb-yang-kurang-maksimal-frdG> accessed 10 June 2020.

18 ibid. 
Ainaya Nadine: Analisis Upaya Pemerintah...

\section{Ganti Rugi Calon Penumpang atas Pembatalan Tiket}

Peranan pengangkutan terhadap kelancaran arus lalu lintas barang dan penumpang disaat pandemi Covid-19 menjadi sangat penting apabila diiringi dengan pengaturan hukum yang memadai. Pengangkutan sebagai perjanjian selalu didahului oleh kesepakatan antara pihak pengangkut dan pihak penumpang atau pengirim. Perjanjian pengangkutan merupakan persetujuan dimana pihak pengangkut mengikatkan diri untuk menyelenggarakan pengangkutan penumpang dan/atau barang dari satu tempat ke tempat tujuan tertentu dengan selamat dan penumpang atau pemilik barang mengikatkan diri untuk membayar biaya pengangkutan. ${ }^{19}$ Berdasarkan pengertian tersebut, pihak yang ada dalam kegiatan pengangkutan adalah pengangkut dan penumpang atau pemilik barang. Sedangkan sifat perjanjian pengangkutan adalah adanya hubungan timbal balik dimana para pihak memiliki kewajiban masing-masing. Perjanjian pengangkutan menimbulkan akibat hukum bagi pelaku usaha dan penumpang sebagai hal yang dikehendaki oleh kedua belah pihak.

Dalam praktek kegiatan transportasi seringkali pengangkut tidak memenuhi kewajibannya secara baik dan benar, oleh karena itu penting bagi penumpang untuk memiliki bukti perjanjian pengangkutan. Adanya perjanjian pengangkutan mempunyai tujuan untuk melindungi hak dari penumpang yang kurang terpenuhi oleh ulah para pelaku usaha angkutan umum karena dengan adanya perjanjian pengangkutan maka memberikan jaminan kepastian hukum bagi pihak-pihak yang mengadakan perjanjian. ${ }^{20}$ Perjanjian pengangkutan tidak diharuskan dalam bentuk tertulis, namun sebagai bukti bahwa pihak-pihak telah memenuhi kewajiban dan memperoleh hak biasanya diterbitkan dokumen pengangkutan.

Untuk pengangkutan orang, sejak penumpang membeli tiket atau karcis, maka dianggap secara diam-diam penumpang tersebut telah menerima penawaran dari pihak pengangkut. Dengan adanya penerimaan penawaran itu maka telah

19 Suwardjoko Warpani, Merencanakan Sistem Pengangkutan (ITB 1990).[46].

20 Ginanjar Hutomo Bangun, 'Perlindungan Hukum Bagi Penumpang Angkutan Umum (Studi Pada Angkutan Umum Jurusan Jatingaleh-UNNES)' (Fakultas Hukum Universitas Negeri Semarang 2012).[19]. 
terjadi persetujuan kehendak (konsensus), dan pada saat itulah telah lahir perjanjian pengangkutan yang bersifat konsensual. ${ }^{21}$ Pada saat pihak penumpang mengikatkan diri sebagai pengguna jasa angkutan, maka pihak pengangkut menyerahkan dokumen pengangkutan berupa tiket kepada calon penumpang yang bersangkutan. Tiket penumpang jelas tercatat mengenai hari maupun jam pemberangkatan yang hendak digunakan mengangkut para penumpang, sehingga pengangkut harus melaksanakan angkutan itu tepat pada hari dan jam yang telah ditentukan dalam tiket penumpang tersebut. ${ }^{22}$

Saat pandemi Covid-19 seperti ini pemerintah telah menegaskan melarang masyarakat untuk mudik. Namun banyak masyarakat yang sudah merencanakan mudik menggunakan transportasi umum atau jasa angkutan dan telah membeli tiket mereka jauh hari sebelum adanya larangan dari pemerintah. Terbitnya Permenhub Nomor PM 25 tahun 2020 menyebabkan banyaknya pembatalan perjalanan transportasi umum secara sepihak oleh penyedia jasa angkutan transportasi umum. Dengan adanya peraturan tersebut pemerintah berharap masyarakat dapat mengurangi aktivitas di luar rumah dan tidak meninggalkan daerah tempat tinggalnya guna mempersempit ruang gerak penyebaran virus Covid-19. Namun tidak ada yang dapat menjamin bahwa pembatalan yang dilakukan oleh penyedia jasa angkutan transportasi umum tersebut tidak membuat penumpang rugi. Oleh karena itu selain membuat peraturan yang berisikan larangan, pemerintah juga melengkapi peraturan tersebut dengan kewajiban penyelenggara sarana transportasi untuk melindungi hak-hak yang seharusnya didapatkan oleh penumpang.

Berdasarkan Permenhub Nomor PM 25 tahun 2020, calon penumpang yang telanjur membeli tiket dijamin haknya untuk mendapatkan kompensasi atas pembatalan perjalanannya berupa pengembalian penuh atas biaya tiket yang sudah dikeluarkan. Namun Permenhub No. 25 tahun 2020 hanya membatasi

21 Fardan, 'Tanggung Jawab Pengangkut Terhadap Penumpang Pada Angkutan Jalan Menurut Undang-Undang Nomor 22 Tahun 2009' (2013) 1 Jurnal Ilmu Hukum Legal Opinion <https://media.neliti.com/media/publications/151185-ID-none.pdf>.

22 ibid.[6]. 
Ainaya Nadine: Analisis Upaya Pemerintah...

kewajiban pengembalian tiket bagi calon penumpang yang membeli tiket untuk perjalanan pada 24 April 2020 sampai dengan tanggal 31 Mei 2020. Sebagaimana tercantum dalam Pasal 1 Permenhub ini, larangan mudik memang mulai berlaku pada tanggal 24 April 2020 sampai dengan tanggal 31 Mei 2020. Jadi bagi penyelenggara sarana transportasi darat dan perkeretaapian serta badan usaha angkutan udara dan laut memiliki kewajiban untuk meniadakan penggunaan sarana transportasi pada rentang tanggal tersebut kecuali yang disebutkan pada pengecualian di Permenhub itu.

Pengaturan terkait pengembalian tiket untuk transportasi darat tertuang pada Pasal 4 Permenhub No. 25 tahun 2020 yang berbunyi, “Penyelenggara sarana transportasi darat sebagaimana dimaksud dalam Pasal 2 wajib mengembalikan biaya tiket secara penuh atau $100 \%$ (seratus persen) kepada calon penumpang yang telah membeli tiket untuk perjalanan pada tanggal sebagaimana dimaksud dalam Pasal 1." Sedangkan pengaturan mengenai perjalanan melalui kereta api tertuang pada Pasal 9 ayat (3), "Penyelenggara sarana transportasi perkeretaapian wajib mengembalikan biaya tiket secara penuh atau 100\% (seratus persen) kepada calon penumpang yang telah membeli tiket untuk perjalanan kereta api antarkota yang dibatalkan sebagaimana dimaksud pada ayat (1)." Pembatalan perjalanan kereta api antarkota yang tertuang dalam Permenhub ini hanya terbatas hanya untuk angkutan penumpang. Lebih lanjut, untuk transportasi laut dan udara juga diwajibkan pengembalian penuh $100 \%$ kepada calon penumpang kapal dan pesawat seperti yang tertuang pada pasal 16 dan pasal 23 Permenhub ini. Namun sedikit perbedaan terdapat pada transportasi laut dan udara, jadi pengangkut memiliki pilihan untuk mengembalikan penuh atau melakukan penjadwalan ulang atau melakukan perubahan rute. Khusus untuk transportasi udara, Permenhub ini mengatur bahwa pengangkut juga dapat memberikan kupon tiket sebesar nilai biaya jasa angkutan udara.

Adanya kewajiban bagi pengangkut untuk melakukan kompensasi merupakan bentuk penerapan dari prinsip tanggung jawab mutlak (absolute liability principle). Istilah tanggung jawab dalam arti liability dapat diartikan sebagai 
tanggung gugat yang merupakan terjemahan dari aansprakelihkheid, dan merupakan bentuk spesifik dari tanggung jawab hukum menurut hukum perdata. Tanggung gugat merujuk pada posisi seseorang atau badan hukum yang dipandang harus membayar suatu kompensasi atau ganti rugi setelah adanya peristiwa hukum. ${ }^{23}$ Prinsip "absolut liability" mengandung makna bahwa barang siapa melakukan perbuatan yang mengakibatkan timbulnya kerugian bagi orang lain, ia harus mempertanggung jawabkan kerugian tersebut tanpa mempersoalkan ada tidaknya kesalahan pada si pelaku. ${ }^{24}$ Dengan demikian prinsip ini sesuai dengan kondisi yang saat ini dikarenakan pada Permenhub Nomor 25 tahun 2020 memberikan perlindungan yang maksimal kepada penumpang karena kerugian yang dialami dengan dibatalkannya perjalanan mudik melalui darat, laut, ataupun udara di Indonesia selama masa Covid-19.

Dalam keadaan Covid-19 seperti ini ketika pengangkut tidak dapat melaksanakan kewajiban yang didasarkan oleh perjanjian yang disebabkan diluar kontrol dan kekuasaan mereka maka kondisi ini lazim disebut sebagai force majeur atau overmacht. Covid-19 merupakan sesuatu peristiwa yang tidak terduga. Namun Menteri Koordinator Bidang Politik, Hukum dan Hak Asasi Manusia, Prof Mahfud MD mengatakan bahwa status Covid-19 sebagai bencana non-alam tidak bisa langsung dijadikan alasan pembatalan kontrak dengan alasan force majeure karena tergantung pada isi klausul kontraknya. Artinya, harus dilihat dulu apakah di dalam klausul kontrak tersebut ada kesepakatan bahwa jika terjadi force majeure isi kontrak bisa disimpangi serta harus dilihat pula pada jenis force majeure yang terjadi yang juga dicantumkan dalam klausul kontrak. ${ }^{25}$ Jika dihubungkan dengan tanggung jawab pengangkut atas dibatalkannya perjalanan mudik, maka berdasarkan Permenhub No. 25 tahun 2020, Covid-19 bukan merupakan keadaan force majeur karena pengangkut masih dibebani tanggung jawab untuk

\footnotetext{
23 Peter Mahmud Marzuki, Pengantar Ilmu Hukum (Kencana Prenada Media Group 2008).[258].

${ }^{24}$ Fardan (n 22)., Op.Cit,[4].

${ }^{25}$ Mochammad Januar Rizki, ‘Penjelasan Prof Mahfud Soal Force Majeure Akibat Pandemi Corona' (Hukum Online, 2020) <https://www.hukumonline.com/berita/baca/lt5ea11ca6a5956/ penjelasan-prof-mahfud-soal-i-force-majeure-i-akibat-pandemi-corona/ > accessed 9 June 2020.
} 
Ainaya Nadine: Analisis Upaya Pemerintah...

memberikan kompensasi sebagai alternatif penyelesaian atas terjadinya suatu tindakan pemerintah yang merugikan.

Meskipun Permenhub telah mengatur kompensasi dapat berupa travel voucher hingga reschedule dan tak harus uang tunai, pada kenyataannya masih banyak calon penumpang yang resah. Calon penumpang transportasi umum yang berniat untuk mengajukan pengembalian uang tunai atas tiket yang telah dibeli mengalami beberapa kesulitan untuk menukarkan tiketnya karena prosesnya membutuhkan waktu yang lama. Selama ini, seringkali keluhan muncul karena kesalahan administrasi yang dilakukan oleh penumpang saat melakukan refund tiket, seperti kesalahan mengisi data, nomor rekening, dan kode booking tiket. ${ }^{26}$

Dengan dikeluarkannya Permenhub 25/2020 juga berimbas pada permintaan refund tinggi, tak terkecuali untuk tiket pesawat. Namun, bentuk refund tiket pesawat yang diberikan justru dikeluhkan calon penumpang. Mereka mengeluhkan, adanya kebijakan refund khusus tiket pesawat yang dikembalikan tidak dengan uang tunai, melainkan voucher. ${ }^{27}$ Terkait dengan transportasi udara, maskapai penerbangan tidak mempunyai kewajiban untuk memberikan refund tiket dalam bentuk uang tunai kepada penumpang yang gagal berangkat akibat larangan pemerintah untuk melakukan perjalanan mudik lebaran 2020. Pihak maskapai diperbolehkan memberikan refund voucher setara 100 persen kepada penumpang yang gagal berangkat. Kementerian Perhubungan mengimbau masyarakat untuk memaklumi kondisi perusahaan maskapai yang sedang dalam kondisi tidak normal, sehingga kebijakan pengembalian tiket tidak bisa dilakukan dalam bentuk tunai. ${ }^{28} \mathrm{Hal}$ ini menjadi permasalahan karena konsumen ingin mendapatkan pengembalian biaya tiket dalam bentuk uang tunai karena

26 Mela Arnani, 'Ramai Keluhan Refund Tiket Kereta, Ini Tanggapan PT KAI' (Kompas.com) <https://www.kompas.com/tren/read/2020/05/14/170000265/ramai-keluhan-refund-tiket-kereta-ini-tanggapan-pt-kai?page=all $>$ accessed 9 June 2020.

27 Nicholas Ryan Aditya, 'Netizen Keluhkan Refund Tiket Pesawat Berupa.......Uang Tunai' (Travel Kompas, 2020) <https://travel.kompas.com/read/2020/04/27/083000327/netizen-keluhkan-refund-tiket-pesawat-berupa-voucer-asosiasi-harap-maskapai?page=all $>$ accessed 9 June 2020..

28 Anitana Widya Puspa, 'Maskapai Refund Tiket Dengan Voucher, Masyarakat Harap Maklum' (Ekonomi Bisnis, 2020) <https://ekonomi.bisnis.com/read/20200420/98/1229876/maskapairefund-tiket-dengan-voucher-masyarakat-harap-maklum> accessed 9 June 2020. 
keperluan untuk berangkat ke suatu tempat terkait dengan event khusus yang harus dihadirinya, yang dibatalkan karena Covid-19, tidak dibutuhkan lagi sehingga bentuk kompensasi lain yang ditawarkan pihak maskapai penerbangan tidak berguna. Konsumen menganggap ada diskriminasi kebijakan antara transportasi darat dengan transportasi udara oleh pemerintah. ${ }^{29}$

Peningkatan permintaan refund yang dilakukan oleh calon penumpang di masa pandemik Covid-19 terlebih lagi bagi yang perjalanan mudiknya dibatalkan karena dikeluarkannya Permenhub No.25 tahun 2020 menimbulkan kekhawatiran bagi pelaku usaha transportasi. Adanya penurunan omzet hingga 50 persen pendapatan di sektor transportasi sejak pandemi Covid-19 melanda Tanah Air. Hal tersebut telah menekan bisnis sektor transportasi nasional yang merata pada semua moda transportasi. ${ }^{30}$ Permenhub No. 25 tahun 2020 dirasa menjadi beban bagi perusahaan transportasi umum.

Dengan dikeluarkannya Permenhub No. 25 tahun 2020 memang merupakan solusi untuk menengahi problematika calon penumpang yang ingin mendapatkan perlindungan dan hak-haknya pada saat kondisi Covid-19. Namun substansi dalam Permenhub itu dirasa kurang tegas karena beban pengembalian dana tiket hanya semata-mata diwajibkan kepada pengangkut. Pemerintah dalam hal selain mengeluarkan peraturan juga diharapkan terlibat dalam proses pengawasan agar hak konsumen pengguna transportasi dapat terpenuhi.

\section{Kesimpulan}

Pemerintah Indonesia telah menetapkan pandemi Covid-19 sebagai bencana nasional dan pemerintah telah mengeluarkan beberapa kebijakan untuk mengurangi potensi penyebaran virus ini, salah satunya adalah dengan Peraturan Menteri Perhubungan Nomor 25 tahun 2020 tentang larangan mudik.

${ }^{29}$ Badan Perlindungan Konsumen Nasional, ‘UU Perlindungan Data Pribadi, Kunci Sukses New Normal Indonesia' (BKPN, 2020) <https:/ / bpkn.go.id/posts/show/id/1603> accessed 10 June 2020.

30 Helmi Fithriansyah, 'Pendapatan Sektor Transportasi Anjlok 50 Persen Gara-Gara Corona' (Liputan 6, 2020) <https://www.liputan6.com/bisnis/read/4225719/pendapatan-sektor-transportasi-anjlok-50-persen-gara-gara-corona> accessed 10 June 2020. 
Ainaya Nadine: Analisis Upaya Pemerintah...

Bagi masyarakat Indonesia mudik bukan hanya mengenai aktivitas mobilitas seseorang, tetapi juga terkait nilai-nilai silaturahmi serta hormat kepada orang tua. Hal inilah yang membuat larangan tentang mudik menjadi sulit.

Terdapat pengenaan sanksi terhadap pelanggar di dalam Permenhub No. 25/2020 pada saat mudik lebaran 2020 sebagai upaya pemerintah untuk melakukan penegakan hukum bagi para pelanggar. Permenhub tersebut dibuat dalam rangka pencegahan dan pengendalian oleh pemerintah dalam rangka membatasi penyebaran Covid-19. Namun ketidakpatuhan dan kurangnya partisipasi masyarakat untuk mematuhi menjadi kendala bagi pemerintah. Jadi, penegakan hukum oleh pemerintah dengan menerapkan sanksi merupakan hal yang penting untuk menunjukkan bahwa wabah Covid-19 adalah masalah serius. Penerapan sanksi tersebut dapat berjalan sempurna jika diimbangi dengan pengawasan bagi para pelanggar.

Sektor transportasi memang menjadi masalah penting karena berkaitan dengan mobilitas masyarakat. Kebijakan pemerintah di sektor transportasi harus bertujuan untuk menemukan titik keseimbangan antara pemerintah, pengangkut, dan penumpang. Larangan mudik melalui Permenhub Nomor 25 tahun 2020 yang mengatur mengenai larangan sudah diimbangi dengan baik dengan pengaturan mengenai ganti rugi yang diberikan. Pembebanan tanggung jawab kepada pengangkut untuk memberikan ganti rugi atas pembatalan perjalanan mudik kepada pengangkut sekiranya dapat membuat masyarakat patuh. Namun, bukan berarti tidak terjadi penyelewengan dalam prakteknya dikarenakan kondisi keuangan pelaku usaha transportasi yang menurun. Namun dalam Permenhub ini tidak dilengkapi dengan pengawasan ganti rugi dan pemberian sarana atau fasilitas kepada pelaku usaha untuk bantuan ganti rugi yang diberikan.

Banyak faktor yang dapat menjadi indikator agar Permenhub dapat berhasil menjadi upaya pemerintah untuk mengurangi penyebaran Covid-19. Mulai dari pengenaan sanksi dan hukuman bagi pelanggar, kepatuhan dan kesadaran masyarakat, serta besarnya ganti rugi yang diterima. Pada intinya penerapan Permenhub akan berjalan dengan lancar apabila terdapat koordinasi atau kerja 
sama antara para pembuat kebijakan dengan pelaku usaha transportasi serta masyarakat.

\section{Daftar Bacaan}

\section{Buku}

Abdulkadir Muhammad, Hukum dan Penelitian Hukum (Citra Aditya Bakti 2004).

Johny Ibrahim, Teori dan Metodologi Penelitian Hukum Normatif (Bayu Media 2007).

Maria Farida Indrati S, Ilmu Perundang-Undangan: Proses dan Teknik Pembentukannya (Kanisius 2007).

Peter Mahmud Marzuki, Penelitian Hukum: Edisi Revisi (Kencana 2005).

Peter Mahmud Marzuki, Pengantar Ilmu Hukum (Kencana Prenada Media Group 2008).

Purwosutjipto, Pengertian Pokok Hukum Dagang Indonesia 3: Hukum Pengangkutan (Djambatan 1991).

Suwardjoko Warpani, Merencanakan Sistem Pengangkutan (Penerbit ITB 1990).

\section{Jurnal}

Fardan, 'Tanggung Jawab Pengangkut Terhadap Penumpang pada Angkutan Jalan Menurut Undang-Undang Nomor 22 tahun 2009' (2013) Jurnal Ilmu Hukum Legal Opinion Edisi 1 Volume 1.

Ginanjar Hutomo Bangun, 'Perlindungan Hukum Bagi Penumpang Angkutan Umum (Studi pada Angkutan Umum Jurusan Jatingaleh-UNNES)' (2012) Skripsi Fakultas Hukum Universitas Negeri Semarang.

Jalaluddin, 'Hakikat dan Fungsi Peraturan Perundang-Undangan Sebagai Batu Uji Kritis Terhadap Gagasan Pembentukan Perda Yang Baik' (2011) Aktualita Vol 6 No 3.

Philipus M. Hadjon, ‘Penegakan Hukum Administrasi dalam Pengelolaan Lingkungan Hidup’ (1995) Jurnal Hukum Ius Quia Iustum Vol 2 No 4.

Zairin Harahap, 'Pengaturan Tentang Ketentuan Sanksi Dalam Peraturan Daerah' (2006) Jurnal Hukum Vol 13 No 1. 
Ainaya Nadine: Analisis Upaya Pemerintah...

\section{Laman}

Adi Briantika, 'Hasrat Represif Negara Dibalik Penerapan PSBB Yang Kurang Maksimal', (Tirto, 2020), <https://tirto.id/hasrat-represif-negara-di-balikpenerapan-psbb-yang-kurang-maksimal-frdG>, dikunjungi pada 10 Juni 2020.

Anitana Widya Puspa, 'Maskapai Refund Tiket dengan Voucher, Masyarakat Harap Maklum', (Ekonomi Bisnis, 2020), <https://ekonomi.bisnis.com/ $\mathrm{read} / 20200420 / 98 / 1229876 /$ maskapai-refund-tiket-dengan-vouchermasyarakat-harap-maklum>, dikunjungi pada 9 Juni 2020.

Badan Perlindungan Konsumen Nasional, 'UU Perlindungan Data Pribadi, Kunci Sukses New Normal Indonesia', (BKPN, 2020), <https:/ / bpkn.go.id/posts/ show/id/1603>, dikunjungi pada 10 Juni 2020.

Bilal Dewansyah, 'Kedudukan Peraturan Menteri Dalam Hierarki Peraturan Perundang-Undangan', (Hukum Online 2014), <https://www. hukumonline.com/klinik/detail/ulasan/lt5264d6b08c174/kedudukanperaturan-menteri-dalam-hierarki-peraturan-perundang-undangan/ >, dikunjungi pada 8 Juni 2020.

Helmi Fithriansyah, 'Pendapatan Sektor Transportasi Anjlok 50 Persen GaraGara Corona', (Liputan 6, 2020), <https://www.liputan6.com/bisnis/ read/4225719/pendapatan-sektor-transportasi-anjlok-50-persen-gara-garacorona>, dikunjungi pada 10 Juni 2020.

Kementerian Kesehatan Republik Indonesia, 'Info Infeksi Emerging Corona Virus', (Infeksi Emerging, 2020), <https://covid19.kemkes.go.id/category/ situasi-infeksi-emerging/info-corona-virus/\#.XwsRcSgzbIU>, dikunjungi pada 8 Juni 2020.

Mela Arnani, 'RamaiKeluhanRefund TiketKereta,IniTanggapanPTKAI',(Kompas, 2020),<https://www.kompas.com/tren/read/2020/05/14/170000265/ ramai-keluhan-refund-tiket-kereta-ini-tanggapan-pt-kai?page=all $>$, dikunjungi pada 9 Juni 2020.

Mochammad Januar Rizki, ‘Penjelasan Prof Mahfud Soal Force Majeure Akibat Pandemi Corona'(Hukum Online,2020)<https://www.hukumonline. com/berita/baca/lt5ea11ca6a5956/penjelasan-prof-mahfud-soal-i-forcemajeure-i-akibat-pandemi-corona/>dikunjungi pada 9 Juni 2020.

Muhammad Choirul Anwar, 'PHK Sudah Terjadi, Sektor Transportasi Terpuruk Kena Corona'(CNBC Indonesia,2020)<https://www.cnbcindonesia.com/ news / 20200427110116-4-154631/phk-sudah-terjadi-sektor-transportasi- 
terpuruk-kena-corona> dikunjungi pada 8 Juni 2020.

Nicholas Ryan Aditya, 'Netizen Keluhkan Refund Tiket Pesawat BerupaUang Tunai'(Travel Kompas,2020)<https://travel.kompas.com/ $\mathrm{read} / 2020 / 04 / 27 / 083000327 /$ netizen-keluhkan-refund-tiket-pesawatberupa-voucer-asosiasi-harap-maskapai?page=all> dikunjungi pada 9 Juni 2020.

Rahmanto Elfian, 'Meski Dilarang, Masih Banyak Yang Paksa Mudik'(Portal Surabaya,2020), <https:/ / portalsurabaya.pikiran-rakyat.com/nasional/pr22380273/meski-dilarang-masih-banyak-yang-paksa-mudik> dikunjungi pada 9 Juni 2020.

Redaksi WE Online, ‘Tak Ada Denda Rp 100 Juta untuk Yang Nekat Mudik, tapi... '(Warta Ekonomi,2020)<https://www.wartaekonomi.co.id/read283321/ tak-ada-denda-rp100-juta-untuk-yang-nekat-mudik-tapi> dikunjungi pada 9 Juni 2020.

World HealthOrganization, 'Situation Report-42'(World HealthOrganization,2020) <https://www.who.int/docs/default-source/coronaviruse/situationreports /20200302-sitrep-42-covid-19.pdf?sfvrsn=224c1add_2> dikunjungi pada 8 Juni 2020.

\section{Perundang-undangan}

Undang-Undang Nomor 12 Tahun 2011 tentang Pembentukan Peraturan Perundang-undangan (Lembaran Negara Republik Indonesia Tahun 2011 Nomor 82).

Undang-Undang Nomor 6 Tahun 2018 tentang Kekarantinaan Kesehatan (Lembaran Negara Republik Indonesia Tahun 2018 Nomor 128).

Peraturan Menteri Perhubungan Nomor 25 Tahun 2020 tentang Pengendalian Transportasi Selama Masa Mudik Idul Fitri Tahun 1441 Hijriah Dalam Rangka Pencegahan Penyebaran Corona Virus Disease 2019 (COVID-19).

How to cite: Ainaya Nadine dan Zulfa Zahara Imtiyaz, 'Analisis Upaya Pemerintah Dalam Menangani Mudik Melalui Peraturan Menteri Perhubungan Nomor 25 Tahun 2020 Pada Masa Covid-19’ (2020) Vol. 3 No. 3 Media Iuris. 
--Halaman ini sengaja dibiarkan kosong-- 